\title{
METABOLIC ASSESSMENT IN PATIENTS WITH URINARY LITHIASIS
}

\author{
CARMEN R. AMARO, JOSE GOLDBERG, JOAO L. AMARO, \\ CARLOS R. PADOVANI
}

\author{
General Hospital, Botucatu Medical School, and Institute of Biosciences of Botucatu, State University of \\ Sao Paulo, UNESP, Botucatu, Sao Paulo, Brazil
}

\begin{abstract}
Introduction: Metabolic investigation in patients with urinary lithiasis is very important for preventing recurrence of disease. The objective of this work was to diagnose and to determine the prevalence of metabolic disorders, to assess the quality of the water consumed and volume of diuresis as potential risk factors for this pathology.

Patients and Methods: We studied 182 patients older than 12 years. We included patients with history and/or imaging tests confirming at least 2 stones, with creatinine clearance $\geq 60 \mathrm{~mL} / \mathrm{min}$ and negative urine culture. The protocol consisted in the collection of 2, 24-hour urine samples, for dosing $\mathrm{Ca}$, $\mathrm{P}$, uric acid, $\mathrm{Na}, \mathrm{K}, \mathrm{Mg}$, Ox and $\mathrm{Ci}$, glycemia and serum levels of $\mathrm{Ca}, \mathrm{P}$, Uric acid, $\mathrm{Na}, \mathrm{K}$, $\mathrm{Cl}, \mathrm{Mg}, \mathrm{U}$ and $\mathrm{Cr}$, urinary $\mathrm{pH}$ and urinary acidification test.

Results: 158 patients fulfilled the inclusion criteria. Among these, 151 (95.5\%) presented metabolic changes, with 94 (62.2\%) presenting isolated metabolic change and $57(37.8 \%)$ had mixed changes. The main disorders detected were hypercalciuria (74\%), hypocitraturia $(37.3 \%)$, hyperoxaluria $(24.1 \%)$, hypomagnesuria $(21 \%)$, hyperuricosuria $(20.2 \%)$, primary hyperparathyroidism $(1.8 \%)$ secondary hyperparathyroidism $(0.6 \%)$ and renal tubular acidosis (0.6).

Conclusion: Metabolic change was diagnosed in $95.5 \%$ of patients. These results warrant the metabolic study and follow-up in patients with recurrent lithiasis in order to decrease the recurrence rate through specific treatments, modification in alimentary and behavioral habits.
\end{abstract}

Key words: urolithiasis; risk factors; salts; metabolic disease; follow-up studies

Int Braz J Urol. 2005; 31: 29-33

\section{INTRODUCTION}

Urolithiasis is the third most common cause of urinary tract disease, predominating in the male gender in a proportion of approximately $2: 1(1)$, and is characterized by a recurrence rate around $50 \%(2)$, reaching $70 \%$ within 10 years (3). It affects from 1 to $20 \%$ of population, and it is estimated that in Brazil there are 5 to $15 \%$ of lithiasis patients.

Several factors are related to a predisposition to urinary lithiasis, such as race, age, gender, occupation, sedentarism, hygienic-dietetic issues, geographic and climatic aspects, hereditariness and metabolic changes $(4,5)$.

The assessment of hygienic dietetic aspects and the diagnosis of potential metabolic changes are factors on which we can interfere, modifying the progression of this pathology that is characterized by high recurrence.

The objective of the present study was to diagnose and to determine the prevalence of metabolic changes present in patients with urinary lithiasis, as well as to assess the quality of water consumed and the diuresis volume as potential risk factors for this pathology. 


\section{MATERIALS AND METHODS}

A prospective study was conducted with 182 patients aged over 12 years old, in the period from February 2000 to December 2001.

Inclusion criteria were previous history of lithiasis with spontaneous, endoscopic or surgical elimination of 2 or more stones, or at least 2 stones currently present in imaging tests, creatinine clearance of $\geq 60 \mathrm{~mL} / \mathrm{min}$, absence of proteinuria and negative urine culture. The protocol for metabolic investigation consisted in collection of two 24-hour urine samples for dosing calcium $(\mathrm{Ca})$, phosphorus $(\mathrm{P})$, uric acid, sodium $(\mathrm{Na})$, potassium $(\mathrm{K})$, creatinine $(\mathrm{Cr})$, magnesium $(\mathrm{Mg})$, citrate $(\mathrm{Ci})$, oxalate $(\mathrm{Ox})$ and cystine. Serum levels of fasting glycemia, calcium, phosphorus, uric acid, sodium, potassium, urea (U), creatinine, magnesium and chlorine $(\mathrm{Cl})$ were measured as well. Fasting urinary $\mathrm{pH}$ was measured with 12-h water restriction, in pHmeter. The urinary acidification test was performed whenever renal tubular acidosis was suspected. Recurrence rate of lithiasis was estimated by dividing the number of formed stones by the length of disease.

Water hardness was assessed from data monthly provided by the Sao Paulo State Basic Sanitation Company through concentrations of magnesium and calcium carbonate, throughout the study period.

Serum dosages were obtained from blood collected in dry tube with separator gel, waiting for 30 minutes and centrifuged by 10 minutes at $300 \mathrm{rpm}$. Calcium was determined in serum by colorimetric test, O-cresolphtalein method using the automation system Technicon RA-XT (normal values 8.5-10.5 mg\%). Urinary calcium was determined by the colorimetric test, performed in dry-chemical automation system (Arsenazo), Vitros $750 \mathrm{~J} \& \mathrm{~J}$ (normal values < $300 \mathrm{mg}$ / $24 \mathrm{~h}$ for male and $<250 \mathrm{mg} / 24 \mathrm{~h}$ for females, or $4 \mathrm{~m} /$ $\mathrm{kg} / 24 \mathrm{~h}$. Phosphorus was dosed by the UV ammonium molybdate test, performed with the automation system Technicon RA-XT (normal values 2-4.5 mg\% for males and $1.3-6.1 \mathrm{mg} \%$ for females in serum, and $340-1000 \mathrm{mg} / 24 \mathrm{~h}$ in urine). Serum and urinary uric acid was dosed by the colorimetric enzymatic test, performed on the automation system Technicon RA-
XT (normal blood values 2.5-7.2 for males and 1.56.0 for females and normal urinary values $300-850$ $\mathrm{mg} / 24 \mathrm{~h}$ ). Serum creatinine was determined by the enzymatic 2-point rate assay, dry-chemical automation system, Vitros $750 \mathrm{~J} \& \mathrm{~J}$ (normal values 0.6-1.4 mg\%). Chlorine was determined by the potentiometer test, performed with dry-chemical automation system, Vitros $750 \mathrm{~J} \& \mathrm{~J}$ (normal values $95-106 \mathrm{mEq} / \mathrm{L}$ ). Serum and urinary sodium was dosed by the potentiometer test, performed with dry-chemical automation system, Vitros $750 \mathrm{~J} \& \mathrm{~J}$ (normal values $147-153 \mathrm{mEq} / \mathrm{L}$ in blood and 40-220 mEq/24h in urine). Potassium was measured by the potentiometer test, performed with dry-chemical automation system, Vitros $750 \mathrm{~J} \& \mathrm{~J}$ (normal values $3.6-5,0 \mathrm{mEq} / \mathrm{L}$ in blood and $30-110$ $\mathrm{mEq} / 24 \mathrm{~h}$ in urine). Serum urea was dosed by the colorimetric test, performed with dry-chemical automation system, Vitros $750 \mathrm{~J} \& \mathrm{~J}$ (normal values 15-40 mg\%). Magnesium was measured by colorimetric test, using xylidine blue, performed with the automation system Technicon RA-XT (normal values $1.6-2.5 \mathrm{mg} \%$ in blood and $48-152 \mathrm{mg} / 24 \mathrm{~h}$ in urine). Proteinuria was dosed by Pyrogallol red method, with automation system Technicon RA-XT (normal values up to $140 \mathrm{mg} / 24 \mathrm{~h}$ ). Urinary citrate was measured by the enzymatic method, automation system Cobas (normal values > $320 \mathrm{mg} / 24 \mathrm{~h}$ for females and $>290 \mathrm{mg} / 24 \mathrm{~h}$ for males). Urinary oxalate was dosed by end-point colorimetric enzymatic method, manual technique with Sigma kit (normal values $4-44 \mathrm{mg} / 24 \mathrm{~h}$ ). Urinary cystine was measured by qualitative method through cyanide-nitroprusside reaction, manual technique. Urinary $\mathrm{pH}$ was measured in pHmeter, Micronal B371.

Results were presented as mean, median, percentage and in the Student's " $t$ " parametric analysis. $\mathrm{P} \leq 0.05$ was considered as statistically significant.

\section{RESULTS}

Of the 182 patients under study, 158 fulfilled all inclusion criteria. A slight predominance was observed for female gender, with 85 women $(53.7 \%)$ and 73 men (46.3\%), ratio 1.17:1. Mean age was $43.28 \pm 13.78$ years for males and $41.24 \pm 12.24$ for 
females. The recurrence rate, expressed as median, was 0.66 for males and 0.5 for females $(p<0.05)$.

We verified that $75 \%$ of patients presented urinary volume between 1000 and $2000 \mathrm{~mL} / 24 \mathrm{~h}$; $16.46 \%>2000 \mathrm{~mL} / 24 \mathrm{~h}$ and only $8.22 \%<1000 \mathrm{~mL} /$ $24 \mathrm{~h}$.

Water for consumption of the population from Botucatu and 22 municipalities presented concentrations of magnesium and calcium carbonate ranging from 10 to $67 \mathrm{mg} / \mathrm{L}$ ( $\mathrm{x}=$ de $36.6 \mathrm{mg} / \mathrm{L}$ ).

Of the 158 patients under study, 151 had at least one metabolic diagnosis, among these, 94 $(62.2 \%)$ had only 1 metabolic change and $57(37.8 \%)$ had mixed changes (Table-1).

The most frequently found metabolic change was hypercalciuria, present in 117 patients (74\%), which was isolated in 62 cases $(53 \%)$ and was associated with other changes in $55(47 \%)$. Hypocitraturia was the second most frequent change, present in $59(37,3 \%)$ patients. Single presentation was found in $12(20.3 \%)$. Slight hyperoxaluria (urinary oxalate between 44 and $100 \mathrm{mg} / 24 \mathrm{~h}$ ) was found in 38 (24\%) patients, with single presentation in $8(21 \%)$. Hyperoxaluria values higher than $100 \mathrm{mg} /$ $24 \mathrm{~h}$ were not seen. Hypomagnesuria was present in $33(21 \%)$ patients. Hyperuricosuria was diagnosed in $32(20.2 \%)$ patients and, among these, only $8(25 \%)$ had single presentation. We found 4 cases of hypercalciuria associated with hypercalcemia, with 3 cases of primary hyperparathyroidism and 1 case secondary to chronic use of loop diuretic (furosemide). Distal renal tubular acidosis was diagnosed in only one female patient. In 7 patients $(4.5 \%)$ it was impossible to establish a metabolic diagnosis.

\section{COMMENTS}

Urinary lithiasis is a frequent disease that mainly affects young male individuals, however recent publications showed less pronounced differences (6). In the sample studied in this work, we found a slight predominance of female $(53.7 \%)$ over male gender $(46.3 \%)$. When assessing the recurrence of lithiasis (number stones/year) we observed it was significantly higher in males. Studies show that the relative risk of stone formation is three times higher in males (7).

As for fluid ingestion and urinary volume, observations have shown that a low urinary volume is a real risk factor for nephrolithiasis and that increased water ingestion should be the initial therapy

Table 1 - Absolute and relative frequency of metabolic changes diagnosed in the 158 patients under study (73 males and 85 females).

\begin{tabular}{|c|c|c|c|}
\hline \multirow[t]{2}{*}{ Metabolic Changes } & \multicolumn{2}{|c|}{ Gender } & \multirow[b]{2}{*}{$\begin{array}{l}\text { Total } \\
\text { N (\%) }\end{array}$} \\
\hline & $\begin{array}{c}\text { Male } \\
\mathbf{N}(\%)\end{array}$ & $\begin{array}{c}\text { Female } \\
\mathbf{N}(\%)\end{array}$ & \\
\hline Hypercalciuria & $55(75.3)$ & $62(72.9)$ & $117(74.0)$ \\
\hline Single & $26(47.2)$ & $36(58.1)$ & $62(53.0)$ \\
\hline Hyperuricosuria & $21(28.7)$ & $11(12.4)$ & $32(20.2)$ \\
\hline Single & $4(19.0)$ & $4(36.3)$ & $8(25.0)$ \\
\hline Hyperoxaluria & 29 (39.7) & $9(10.5)$ & $38(24.0)$ \\
\hline Single & $4(13.7)$ & $4(44.4)$ & $8(21.0)$ \\
\hline Hypocitraturia & $26(35.6)$ & $33(38.8)$ & $59(37.3)$ \\
\hline Single & $1(3.8)$ & $11(33.3)$ & $12(20.3)$ \\
\hline Hypomagnesuria & $13(17.8)$ & $20(23.6)$ & $33(20.9)$ \\
\hline Primary hyperparathyroidism & $1(1.4)$ & $2(2.3)$ & $3(1.8)$ \\
\hline Secondary hyperparathyroidism & $1(1.4)$ & $\mathbf{0}$ & $1(0.6)$ \\
\hline Distal renal tubular acidosis & $\mathbf{0}$ & $1(1.3)$ & $1(0.6)$ \\
\hline No change & $4(5.5)$ & $3(3.5)$ & $7(4.5)$ \\
\hline
\end{tabular}


for preventing recurrent stones (8-10). When the patients' urinary volume was assessed, we found only $8.2 \%$ of the cases presenting diuresis lower than 1000 $\mathrm{mL} / 24 \mathrm{~h}$. These findings could be explained by the fact that these patients probably were instructed to increase their fluid ingestion prior to the study. Therefore, in the present study, urinary volume itself was not a significant risk factor for lithiasis, and was significantly reduced in only $8.2 \%$ of patients.

Aspects related to the composition of water consumed by the population and its relation to the incidence of renal lithiasis are inconclusive and sometimes contradictory (11). Only calcium and magnesium are found in significant concentrations in natural water, so that water hardness is defined by the total concentration of magnesium and calcium carbonate in the water. Smooth or soft waters contain approximately 50 to $75 \mathrm{mg} / \mathrm{L}$ of calcium carbonate $\left(\mathrm{CaCO}_{3}\right)$, being suitable for public consumption. Waters containing 75 to $150 \mathrm{mg} / \mathrm{L}$ of $\mathrm{CaCO}_{3}$ are considered moderately hard with changes in taste and are considered as risk factor for urinary lithiasis (11).

The water delivered for public consumption in the city of Botucatu and 22 municipalities presents physical-chemical characteristics that classify it as a soft water (10 to $67 \mathrm{mg} / \mathrm{L}$ of $\mathrm{Mg}$ and $\mathrm{CaCo}_{3}$ ). Thus, values found concerning the hardness of water consumed by patients with lithiasis do not characterize the water as a risk factor for lithogenesis.

In Brazil, the experiences of several centers for study on lithiasis showed that (93 to 97\%) of patients with lithiasis had metabolic diseases (12). In the present study, metabolic changes were diagnosed in $95.5 \%$ of patients with lithiasis.

Of the 158 patients under study, 151 presented at least one metabolic diagnosis; among these, 96 $(63.6 \%)$ showed a single metabolic disorder and 55 (36.4\%) had mixed metabolic changes. This sample was similar to a large Argentinean study with 2612 lithiasis patients, where $61.5 \%$ of metabolic changes were single and $31.2 \%$ were mixed (13).

In the present study, hypercalciuria was the most frequent change, being present in 117 (74\%) cases. Hypocitraturia was the second most frequent change, detected in $37.3 \%$ of patients. Studies on hypocitraturia showed a highly variable prevalence in the single presentation, reaching $62 \%$ when associated with other disorders (14). The citrate acts on prevention of lithiasis due to its dissolving effects and by inhibiting the crystallization of calcium and uric acid salts (15). Citraturia is not directly influenced by the ingestion of alimentary citrate, but by systemic acid-basic changes produced by a certain diet. Diets rich in proteins and excessive physical exercise cause reduced citraturia (16).

Slight hyperoxaluria was present in $24.1 \%$ of patients. The role of slight hyperoxaluria $(<100$ $\mathrm{mg} / 24 \mathrm{~h}$ ) in calcium lithiasis is quite controversial. As for the association between hyperoxaluria and hypercalciuria, no positive correlation was observed. Studies with pure calcium oxalate stones concluded that they were more frequent in patients with normal calcium excretion and that mixed stones made of calcium phosphate and oxalate were more frequently found in patients with hypercalciuria (17). Other authors observed that small increases in urinary oxalate would be more critical than similar increases in calcium in the process of urinary supersaturation by calcium oxalate (18). In our study, we found $43.6 \%$ of hyperoxaluria associated with hypercalciuria in male patients and only $8 \%$ of this association in females.

Hypomagnesuria was diagnosed in $21 \%$ of patients with lithiasis. The low urinary excretion of magnesium has been considered as a potential risk for formation of calcium stones and its supplementation has been shown to be effective in reducing or preventing the recurrence of urinary calcium lithiasis (19).

Hyperuricosuria was observed in $20.2 \%$ of our patients. National data published by MULTILIT (1995) (12) showed a mean national frequency of $27.2 \%$ of excessive urinary excretion of uric acid, however, when each Brazilian region was analyzed separately, large different were detected in its frequency, ranging from $6.3 \%$ in Belo Horizonte to $69 \%$ in Alagoas. Probably this could be due to different dietetic habits.

Primary hyperparathyroidism was diagnosed in $1.8 \%$ of patients with calcium lithiasis. Type I or distal renal tubular necrosis with metabolic acidosis was diagnosed in only 1 patient $(0.6 \%)$. 
Recent randomized prospective studies, comparing patients who received specific dietetic orientations, according to the metabolic changes diagnosed and non-studied patients who followed general orientations showed that after 3 years the development of new stones was significantly lower in the group that had been given specific orientations, when compared with patients receiving general orientations, showing the importance of specific orientations derived from a metabolic diagnosis (10).

\section{REFERENCES}

1. Lancina Martin JA, Rodriguez-Rivera GJ, Novas Castro S, Rodriguez Gomez I, Fernandez Rosado E, Alvarez Castelo L, et al. [Metabolic risk factors in calcium urolithiasis according to gender and age of the patients] Actas Urol Esp. 2002; 26: 111-20 [Spanish].

2. Joual A, Rais H, Rabii R, el Mrini M, Benjelloun S: Epidemiology of urinary lithiasis. Ann Urol. (Paris) 1997; 31: 80-3.

3. Tiselius HG: Stone incidence and prevention. Clin Urol. 2000: 26: 452-62.

4. Ekane S, Wildschutz T, Simon J, Schulman CC: Urinary lithiasis: epidemiology and physiopathology. Acta Urol Belg. 1997; 65: 1-8.

5. Pak CY, Resnick MI, Preminger GM: Ethnic and geographic diversity of stone disease. Urology. 1997; 50: 504-7.

6. Robertson WG, Peacock M, Baker M, Marshall DH, Pearlman B, Speed R, et al.: Studies on the prevalence and epidemiology of urinary stone disease in men in Leeds. Br J Urol. 1983; 55: 595-8.

7. Shekarriz B, Stoller ML: Metabolic evaluation of stone disease. Int Braz J Urol. 2001; 27: 10-18.

8. Curhan GC, Willett WC, Speizer FE, Stampfer MJ:
Beverage use and risk for kidney stones in women. Ann Intern Med. 1998; 128: 534-40.

9. Pak CY: Medical prevention of renal stone disease. Nephron. 1999; 81: 60-5.

10. Pearle MS: Prevention of nephrolithiasis. Curr Opin Nephrol Hypertens. 2001; 10: 203-9.

11. Agreste SA, Schor N, Heilerg IP: Papel da constituição físico química da água potável na litogênese renal. J Bras Nefrol. 2001; 23: 45-8.

12. Laranja SMR, Heilberg IP, Coelho STSN, Novoa CG, Schor N: Estudo multicêntrico de litíase renal no Brasil (MULTILIT). In: Schor N, Heilberg IP (eds.), Calculose Renal, Fisiopatologia, Diagnóstico, Tratamento. São Paulo, Sarvier. 1995; pp. 295-338.

13. Del Valle E, Spivacow R, Zanchetta JR: Metabolic changes in 2612 patients with nephrolithiasis. Medicina. (B Aires) 1999; 59: 417-22.

14. Ayusso LL, Schor N: Avaliação de pacientes com litíase renal em região de clima quente. J Bras Nefrol. 2001; 23: 205-12.

15. Hallson PC, Rose GA, Sulaiman S: Raising urinary citrate lowers calcium oxalate and calcium phosphate crystal formation in whole urine. Urol Int. 1983; 38: 179-81.

16. Rebelo MAP. Hipocitratúria. In: Schor N, Heilberg IP (eds.), Calculose Renal, Fisiopatologia, Diagnóstico, Tratamento. São Paulo, Sarvier. 1995; p. 105.

17. Grases F, Conte A, Coll R, Genestar C: The role of hyperoxaluria in the formation of calcium oxalate urinary calculi, and its association with other biochemical measurements. Scand J Urol Nephrol. 1990; 24: 211-3.

18. Robertson WG, Hughes H: Importance of mild hyperoxaluria in the pathogenesis of urolithiasis- new evidence from studies in the Arabian peninsula. Scanning Microsc. 1993; 7: 391-402.

19. Asplin JR, Murray JF, Coe FL: Nephrolithiasis. In: Brenner BM (ed.), The Kidney, Brenner \& Rector's. Philadelphia, WB Saunders. 2000; pp. 1774-819.

\footnotetext{
Correspondence address:

Dr. Carmen R. Amaro

Av. Camilo Mazoni, 874, J. Paraíso

Botucatu, SP, 18610-460, Brazil

Fax: + $55143882-5766$

E-mail: btamaro@uol.com.br
}

Received: June 17, 2004

Accepted after revision: October 28, 2004 